2. Драчёва С.И. Экспериментальное исследование вербального содержания этнической концептуальной системы // Текст: структура и функционирование. Вып. 2. Барнаул: Изд-во Алт. ун-та, 1997. 160 с.

3. Карасик В.И. Культурные доминанты в языке // Языковая личность: культурные концепты: сб. науч. тр. Волгоград, Архангельск Перемена, 1996. С. 3 - 16.

4. Лихачев Д.С. Концептосфера русского языка. - М.: Русская словесность, 1997. -282 c.

5. Попова 3.Д., Стернин И.А. Семантико-когнитивный анализ языка. Монография. Воронеж: изд-во «Истоки», 2007. 250 с.

6. Стернин И.А. Методика исследования структуры концепта // Методологические проблемы когнитивной лингвистики / Под ред. И.А. Стернина. Воронежский государственный университет, 2001. С. 58 - 65.

\title{
Экзистенциальная традиция в романе М. Петросян «Дом, в котором...»
}

Баишева К.В., магистрант, Северо-Восточный федеральный университет, 2. Якутск E-mail: klavabaisheva@yandex.ru

Научный руководитель: к.филол.н., доцент Штыгамева О.Г.

В философии экзистенциализма основной темой выступает человек как уникальное духовное существо, способное к выбору собственной судьбы. То есть данная философская проблема была актуальна с тех времен, как человек стал размышлять о проблемах смысла жизни, отношения человека к смерти и абсурдности бытия.

Если в зарубежной литературе представителями экзистенциальной литературы были Ж.-П. Сартр, А. Камю, А. Мердок, У. Голдинг и др., то в отечественной литературе (хоть и не было четко выделенного такого течения в русской литературе) приверженцами экзистенциализма были Ф.И. Тютчев, Ф.М. Достоевский и Л.Н. Толстой.

Но экзистенциальная философия не теряет свою актуальность и по сей день. Так, например, в романе М. Петросян «Дом, в котором...» раскрываются проблемы экзистенциальной литературы.

Армянская писательница Мариам Петросян обрела свою популярность после написания своего первого и единственного на данный момент романа на русском языке «Дом, в котором...» (2009). Петросян была награждена «Русской премией» (2009), что дало критикам обратить на нее внимание. Так, критики (М. Галина, О. Лебедушкина, Д. Быков, К. Рождественская, А. Немзер и др.) назвали «Дом, в котором...» «большой» книгой, романом десятилетия и даже «дверью в ту новую литературу, которую все ждали» [1].

Вокруг произведения Мариам Петросян очень много спорных вопросов, требующих ответа. Одним из таких вопросов выступает раскрытие философских проблем, в частности, относящиеся к экзистенциализму. Н.С. Шиловская считает, что 
«экзистенциальное может выступать просто как раскрывающее внутренний мир человека, обращенное к человеку, рассказывающее о человеке» [5]. И далее исследователь приводит в пример произведение Мариам Петросян. Таким образом, Н.С. Шиловская подтверждает наше мнение о том, что роман несет в себе экзистенциальный подтекст, но при этом не призывает полностью назвать произведение Петросян экзистенциальной литературой.

В романе «Дом, в котором...» основной экзистенциальной проблемой выступает проблема сущцости и существования. Применительно к человеку, существование предшествует сущности. Свою сущность он обретает по ходу существования, то есть человек делает себя сам.

Герои романа М. Петросян - дети (подростки), необычность которых заключается в их неполноценности: одни - без какой-либо конечности (безрукие, «колясники»), вторые - слепые, третьи - больны душевно. Но и среди них есть абсолютно здоровые дети, от которых отказались родители, которых просто сдали в школу-интернат - Дом. Сам Дом - абстрагирован от реальности и воспринимается читателями как ирреальный мир. При всем этом Дом в романе выступает как нечто живое, живущее по-своим правилам и законам. Дом может принять ребенка или же наоборот, «отрыгнуть его в Наружность (реальный мир)». Когда Дом принимает нового жильца, то он делает его частью Дома, помогает раскрыть свою настоящую сущность. Так, например, Слепой гуляя по коридорам Дома внезапно оказывается в Лесу и принимает вид неведомого животного: «Он [Лес] был печален, но в нем было счастье Слепого, близость луны и жизнь ночи. Это длилось недолго, а потом Слепой убежал в чащу обнюхивать мшистые стволы, скакать по влажным листьям и кататься по земле. Он делал это ликуя...» [2; стр. 145]. А вот с новичками Дом и его жители обходятся немного иначе: «Новичок - это всегда событие. Они совсем-совсем другие. На них интересно даже просто смотреть. Смотреть и видеть, как они понемногу меняется, как Дом засасывает их, делая своей частью» [2; стр. 383]. Так или иначе все жильцы несут в себе частичку Дома, их настоящая сущность раскрывается именно во время существования в Доме.

Следующим ключевым понятием в экзистенциальной философии выступает свобода. Мыслители экзистенциализма понимают под существованием человека свободное существование, а свобода в свою очередь подразумевается не как «свобода духа», а «свобода выбора», которую никто не может отнять у человека.

Тема свободы в романе Петросян является ключевой. Так, например, по мнению критика Ксении Тихомировой, роман «Дом, в котором...» строится на философской проблеме свободы: «их спор [спор Слепого и Сфинкса] - главный конфликт в этом сложном романе. Реальность или Изнанка? Прожить свою жизнь или уйти в придуманный мир? И в чем истинная свобода: принять свою человеческую судьбу или отвергнуть ее? Какой выбор достойнее?» [4].

Даже сам образ дома является неким символом свободы-несвободы: «Чаще всего по ходу чтения нам будет попадаться мифологема о яйце, из которого вылупляется мир. В романе этот образ ключевой. Серый Дом - огромное яйцо, заключающее в себе и целую Вселенную, и множество «птенцов», которые в финале должны разбить его скорлупу и выйти в какую-то другую реальность. Об этом прямо говорит, к примеру, Курильщик, когда спорит со Сфинксом о свободе. То же происходило и с предыдущим поколением; тогда маленький Кузнечик (будущий Сфинкс) разбил стекло подвала, чтобы выпустить «старших» на волю» [4]. 
Сами герои романа по-своему свободны: для кого-то это является собственным выбором, для другого - навязанной мыслью: «Ничего я не выбирал! < ..> Моего согласия никто не спрашивал! Попади я во вторую [группу], должен был бы приноравливаться к Крысам. К их дурацкому имиджу, который они себе выбрали до меня и без меня. Это ты называешь свободой?» [2; стр. 332]. Некоторым персонажам сложно оторвать себя от Дома, до такой степени они слились, что один не может без другого: «...мне [Сфинксу] никогда не стать свободным, пока я не уйду от тебя [от Дома], хотя я лгал Курильщику, что свобода в человеке, где бы он ни находился. Я боялся, что ты изменил меня, сделал своей игрушкой, я хотел доказать себе, что могу прожить без тебя» [2; стр. 935].

Но так или иначе в конце, когда наступает момент покидать Дом, каждый должен выбрать для себя: уйти в Наружность и слиться с обычными людьми или уйти на Изнанку - связать себя с ирреальным миром Дома.

В философии экзистенциализма существование человека включает в себя ответственность: не только за себя, но и за окружающих. В «Доме, в котором...» герои живут стаями, имеют вожака, но при этом каждый за себя. Поэтому вопрос ответственности именно как принцип экзистенциализма очень спорен.

В своем произведении Петросян в отличие от экзистенциалистов снимает ответсвенность со своих героев за счет Большой игры, по сценарию которого живут домовцы. Так, например, убийство Помпея, посягнувшего на место вожака Дома, не рассматривается как преступление. Убийство в романе воспринимается как должное, как часть сценария. Поэтому только Курильщик, который не до конца понимает правила жизни в Доме, начинает возмущаться, его окатывает страх и отвращение от остальных домомвцев. А Табаки остался безразличным к такому исходу Помпея:

«- А вы все знали, что Слепой его убьет... <...> Вы знали, - повторил я [Курильщик]. <..> Сфинкс был уверен в этом, когда говорил с ним сегодня... Теперьто я понимаю...

- Ну? - спросил Табаки. - Допустим, мы знали. Что из того?

Ему не было ни противно, ни стыдно. Ни капли» [2; стр. 283].

Слепого так и никто не осудил, не оклеймил преступником или убийцей, потому что он действовал по законам Дома, играл по сценарию.

Критик Т. Соловьева пишет: «Сам факт существования неких неписаных, не ими [жильцами Дома] придуманных правил снимает с героев вину за большинство поступков, потому что игра - это несерьезно. <...> Снятие с себя ответственности самим фактом игры, зачастую очень страшной и жестокой, отсылает нас к целому пласту литературы: «Повелителю мух» Голдинга, «Песням мертвых детей» Тоби Литта...» [3].

Исходя из вышенаписанного в романе Мариам Петросян можно выделить традиции экзистенциальной философии. Персонажи романа находятся в поисках своей сущности, тема свободы и свободы выбора выходит на передний план повествования, а также отсылка Т. Соловьевой к творчеству Голдинга дает нам подтверждение, что в романе М. Петросян традиции экзистенциализма имеют место быть.

\section{Список литература:}

1. Быков Д. Порог, за которым // [Электронный ресурс] Издательство «Livebook».URL:http://livebooks.ru/goods/dom_v_kotorom/dmitriy_bikov_o_dome/ (Дата обращения: 02.03.16). 
2. Петросян М. Дом, в котором... М.: Livebook, 2015. - 960 с.

3. Соловьева T. Лес vs. Наружность. О романе Мариам Петросян «Дом, в котором...» // [Электронный ресурс] Журнальный зал. URL: http://magazines.russ.ru/voplit/2011/3/so9.html (Дата обращения: 02.12.16).

4. Тихомирова К. Книга, в которой... // Наше наследие - иллюстрированный культурно-исторический журнал [Электронный ресурc]. URL: http://www.nasledierus.ru/red_port/dom.php (Дата обращения: 07.12.16).

5. Шиловская Н.С. Гуманизм, экзистенция и социальное // [Электронный ресурс] $\begin{array}{llllll}\text { Вестник Мининского у } & \text { университета. № } & 3 & - & 2013 .\end{array}$ URL:http://vestnik.mininuniver.ru/reader/search/gumanizm-ekzistentsiya-i-sotsialnoe/ (Дата обращения: 08.12.16).

\section{Термины-эпонимы в английском языке}

\section{Балабкин И.С., студент, ГАПОУ РС (Я) «Алданский политехнический техникум», 2. Алдан E-mail: politeh@rambler.ru}

Научный руководитель: преподаватель Хомустахова Ю.Г.

Эпонимы - очень интересное явление в языке. Подобно многим терминам в различных областях науки, термин «эпоним» имеет греческое происхождение. Название «эпоним» происходит от “Ероnymos”- дающий имя. Эпоним - имя человека, которое наследует предмет, явление, понятие и т.д., к открытию или созданию которого этот человек имеет непосредственное отношение.

Интерес к теме вызван тем, что многие и не подозревают, сколько слов в английском языке произошли от фамилий людей, ставших настолько известными, что их имена стали частью языка. Эпонимы интересны и тем, что при их изучении узнаешь много исторических фактов, мифологию, судьбы необычных людей. Этим и обусловлена актуальность нашего исследования.

\section{Виды эпонимов}

Говоря о сфере употребления эпонимов в английском языке, следует отметить, что они используются как в общеупотребительной лексике, так и в научной терминологии. Можно выделить несколько основных групп эпонимов и эпонимических конструкций:

Географические эпонимы

Среди самых очевидных эпонимов названия мест: во всем мире существуют тысячи улиц и зданий, а также сотни городов, названных в честь выдающихся людей: исследователей, политиков, генералов, миллионеров. Симон Боливар, воевавший за независимость испанских колоний в Америке, увековечил свое имя в названии страны - Бливия, и стал ее первым президентом. Однако в географии случаются «несправедливости». Колумб открыл Америку, но названа она не в его честь. Самому Колумбу только один штат в Америке и достался - Колумбия. А вот у Америго Веспуччи были хорошие друзья, которые предложили назвать Новую Землю в честь 